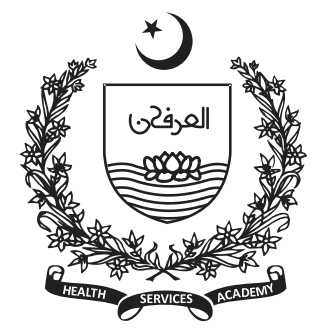

\title{
Are Socio-Economic Determinants Important for Patient's Knowledge, Attitude and Practice: Evidence from Hepatitis-C Patients
}

\author{
Nida Tahir ${ }^{1}$, Saqib Amin², Muhammad Tariq Rafiq ${ }^{3}$
}

1University of Lahore,

Pakistan, Specialization in

Paediatric Nursing

Superior University,

Lahore, Pakistan

${ }^{2}$ National College of Business Administration and Economics, Lahore, Pakistan

${ }^{3}$ Centre for Sport and

Exercise Sciences,

University of Malaya,

Kuala Lumpur, Malaysia

Corresponding Author:

Nida Tahir

Email:

nidatahir152@gmail.com

\begin{abstract}
Background: Hepatitis $C$ is one of the commonest and fatal diseases in Pakistan as well as around the World. There were around 17 million people all over Pakistan with infected Hepatitis C virus (HCV). Patient's knowledge, attitude and practice are important determinants to combat this fatal disease. In this regard, socioeconomic factors including low income, low educational status and inadequate housing conditions may effect on patient's knowledge, attitude and practice. The main objective of this study was to identify the impact of socio-economic determinants on patient's knowledge, attitude and practice.
\end{abstract}

Methods: The convenient sample technique was used to collect the data of 278 patients of HCV from Hepatitis C Clinic at Social Security Teaching Hospital Multan Road Lahore. Logistic regression was applied to identify the socioeconomic determinants that was crucial important regarding patient's knowledge, attitude and practice

Results: The results indicate that those patients who had low educational status, low income, unemployed, and inadequate housing conditions had poor performance regarding knowledge, attitude and practices towards Hepatitis C. There was a significant association between socio-economic determinants and its effects on patient's knowledge, attitude and practice.

Conclusion: Poor knowledge, negative attitude and bad practice towards $\mathrm{HCV}$ were the main reasons behind poor socioeconomic determinants. Poor knowledge, bad practices, helpless peoples, low income, low status, inadequate housing conditions and educational status effects on patient's health.

Keywords: Socioeconomic determinants, knowledge, attitude, practice, patients, hepatitis $\mathrm{C}$ virus

\section{Introduction}

$\mathrm{E}$ Viral hepatitis is a serious disease affecting the two billion peoples in the world (1). Hepatitis viruses are the most common cause in the world but other infections, toxic substances, and autoimmune diseases can also cause hepatitis C disease (2). Hepatitis C virus (HCV) is mostly transmitted through exposure to infective blood. This may happen through transfusions of $\mathrm{HCV}$ contaminated blood and blood products, contaminated injections during medical procedures, and through injection drug use. The prevalence of the disease varies all over the world. It can be considered 
low in the United Kingdom and the Scandinavian Peninsula $(0.01 \%$ to $0.1 \%)$, in the Americas, Western Europe, Australia and South Africa (0.2\% to $0.5 \%)$. It is intermediate in Brazil, Eastern Europe and some regions in Africa and Asia. The highest rates were found in Egypt (17\% to $26 \%$ ) and Pakistan (4.5\% to $8 \%$ ). Incidence of Hepatitis $\mathrm{C}$ varies in different areas of Pakistan and its range is from $4.5 \%$ to $8 \%$. The main reasons for the rapid spread of this disease are lack of knowledge, poor medical facilities and practices of peoples especially in the least developed countries (3). It causes serious health problems all around the world like higher mortality and longer morbidity costs to patients. The disease is commonly present in Canada, America, United Kingdom, Western Europe, Australia and South Africa $(0.2 \%-0.5 \%)$ (4). Hepatitis C is spreading in Pakistan. Hepatitis $\mathrm{C}$ transmitted through contaminated needles, unsterilized instrument, blood product transfusion, used blades and rubber, poor personal hygiene, tattoos, wore a piercing and sexual intercourse. The disease does not spread due to hugging, kissing and mother breast milk and sharing food. Recent studies have shown that 10 million people in Pakistan are being infected with $\mathrm{HCV}$ and the prevalence rate is $4.8 \%$ (5).

There is also evidence connecting HCV infection with other determinants of health, including age, gender, ethnicity, low educational status and unstable housing. Peoples have low income, they are not educated about infected disease hepatitis $C$ virus, and then they ultimately suffer from many situations (6). Socioeconomic determinants are affected on the patient physical and mental health. Socioeconomic determinant refers to a person's situation in a society and based on criteria such as education, employment, income, and value of residence place. In Canada, the peoples who's are drug user that are infected with hepatitis $C(7)$.

Hepatitis $C$ is spreading in Pakistan. Hepatitis C transmitted through contaminated needles, unsterilized instrument, blood product transfusion, used blades and rubber, poor personal hygiene, tattoos, wore a piercing and sexual intercourse. The disease does not spread due to hugging, kissing and mother breast milk and sharing food (5).

There is also evidence connecting Hepatitis $C$ virus infection with other determinants of health, including age, gender, ethnicity, low educational status and unstable housing conditions. A research article reported that the peoples who have low income, they are not educated about infected disease hepatitis $C$ virus, and they ultimately suffer from the disease (6). Socioeconomic determinants are affected on the patient physical and mental health. Socioeconomic determinant refers to a person's situation in a society and based on criteria such as education, employment, income, and value of residence place.

Housing plays an important role in the HCV infected person in relation to comprehensive societal processes with an individual's immediate social and physical environment that impact on health and well-being. Housing is powerfully connected with risk factors for exposure and transmission, and with the care and health of persons infected with HCV (8). Economic and financial resources of patients and their families are important factors - the higher the income level and educational status the lower the incidence of $\mathrm{HCV}$. Employed persons have high risk of $\mathrm{HCV}$ as compared to unemployed persons. Regardless of income, employed patients have a higher survival rate than unemployed patients (9). Knowledge is defined as the delivered by the interaction with possess condition where people themselves build their understanding of the world through experience. It is necessary that peoples must have knowledge about HCV (10).

An attitude also plays an important role in the infected $\mathrm{HCV}$ patient, which ultimately effects on the patient's health. Attitude is defined as the good and horrible response to an object, individuals, circumstances or different parts of world. An individual's behavior can be explained by the attitude (11). People's attitude about HCV may be positive or negative. There are many factors that effect on patients' attitude such as inadequate knowledge, helpless peoples, low income, low social status, educational status and diminishing danger factors (12). Peoples have bad practices regarding $\mathrm{HCV}$ because of poor knowledge and negative attitude. When patients prick needles, they get infected with HCV because they don't' have any knowledge about this disease. They don't use gloves when open wounds or sores of the infected patients with HCV (13).

Pakistan is a developing country in the world with low educational and health status, due to insufficient amount of budget spent on education and health (14). The health of people with low incomes often suffers. A study reported that the $41.0 \%$ participants did not know about the disease and $10.6 \%$ stated that they have no information about the treatment of HCV (15). 
Omland et al. (2013) reported the result of socioeconomic determinants on hepatitis C infected patients in Denmark (16). They pointed out that employment, income and education were significantly associated with risk of HCV infection in Denmark. The ratio shows that employed persons were less likely to have risk of $\mathrm{HCV}$ infection as compared to unemployed and disability pensioners. There was low possibility in educated persons to have risk of $\mathrm{HCV}$ infection as compared to less educated persons. The odd ratios indicated that rich persons were less likely to have risk of $\mathrm{HCV}$ infection as compared to poor persons. Regardless of income, employed patients had a higher survival rate than unemployed patients.

Another study revealed that rural population had negative attitude towards the patients of hepatitis $B$ and C. Further results also indicated that people having low income and less education also had negative attitude towards $\mathrm{HCV}$, which may be due to lack of knowledge about the disease (17). In Australia, people living in the poorest areas had high rates of unemployment and injection drug users were more likely to be infected with Hepatitis C (18). The main objective of this study was to identify the impact of socio-economic determinants on patient's knowledge, attitude and practice.

\section{Methodology}

Study design and setting:

The study was a descriptive cross-sectional study. It was conducted at Social Security Teaching Hospital Multan Road Lahore, Pakistan from November 2019 to February 2020.

\section{Subjects and selection:}

The subjects of study were the patients infected with $\mathrm{HCV}$. The patients of HCV were selected from the Hepatitis C Clinic at Social Security Teaching Hospital Multan Road Lahore.

\section{Sample size}

The total sample size of the current study was 278 patients of $\mathrm{HCV}$.

\section{Data collection}

The convenient sample technique was used to collect the data.

\section{Questionnaire:}

The questionnaire of the study was adopted from four research articles $(5,8,16)$. The questionnaire of the study covered the socioeconomic determinants, knowledge, attitude \& practices towards HCV.

\section{Ethical Aspects:}

Confidentiality of the participants was maintained. The Study did not harm any participant. The participants were volunteer to participate in the study and they had the right to withdraw from the study at any time.

\section{Data Analyzed:}

Data was analyzed using Statistical Package for the Social Sciences version 21.0 statistical software. The dependent and independent variables were analyzed by using the logistic regression.

\section{Results}

The socioeconomic determinants of the patients of $\mathrm{HCV}$ are explained in table 1 . The answers of the knowledge, attitude and practice of the patients are explained in Table 2. Table 3 demonstrate the logistic regression analysis.

Table 1. Socioeconomic determinants of the patients

\begin{tabular}{|c|c|c|c|c|}
\hline & $\begin{array}{c}\text { Socioeconomic } \\
\text { Determinant }\end{array}$ & & Frequency & Percentage \\
\hline \multirow[t]{2}{*}{ 1) } & Gender & $\begin{array}{c}\text { Male } \\
\text { Female }\end{array}$ & $\begin{array}{l}152 \\
126\end{array}$ & $\begin{array}{l}54.51 \% \\
45.49 \%\end{array}$ \\
\hline & & Total $=278$ & & \\
\hline \multirow[t]{2}{*}{ 2) } & Age & $\begin{array}{l}>50 \\
>60 \\
>70 \\
>80\end{array}$ & $\begin{array}{c}66 \\
109 \\
50 \\
53\end{array}$ & $\begin{array}{l}23.8 \% \\
39.4 \% \\
17.8 \% \\
19.0 \%\end{array}$ \\
\hline & & Total $=278$ & & \\
\hline \multirow[t]{2}{*}{ 3) } & Marital status & Married & 278 & $100 \%$ \\
\hline & & Total $=278$ & & \\
\hline \multirow[t]{2}{*}{ 4) } & Residence & $\begin{array}{l}\text { Rural } \\
\text { Urban }\end{array}$ & $\begin{array}{c}54 \\
223\end{array}$ & $\begin{array}{l}19.5 \% \\
80.5 \%\end{array}$ \\
\hline & & Total $=278$ & & \\
\hline \multirow[t]{2}{*}{ 5) } & $\begin{array}{l}\text { Employment } \\
\text { status }\end{array}$ & $\begin{array}{c}\text { Employed } \\
\text { Not in } \\
\text { Employment }\end{array}$ & $\begin{array}{l}135 \\
138\end{array}$ & $\begin{array}{l}47.00 \% \\
53.00 \%\end{array}$ \\
\hline & & Total $=273$ & & \\
\hline \multirow[t]{2}{*}{ 6) } & $\begin{array}{l}\text { Educational } \\
\text { Status }\end{array}$ & $\begin{array}{l}\text { Low educational } \\
\text { status } \\
\text { Medium } \\
\text { educational status }\end{array}$ & $\begin{array}{l}170 \\
108\end{array}$ & $\begin{array}{l}61.4 \% \\
38.8 \%\end{array}$ \\
\hline & & Total $=278$ & & \\
\hline \multirow[t]{2}{*}{ 7) } & Income status & $\begin{array}{l}\text { Low Income } \\
\text { No Income }\end{array}$ & $\begin{array}{c}196 \\
82\end{array}$ & $\begin{array}{l}70.8 \% \\
29.2 \%\end{array}$ \\
\hline & & Total $=278$ & & \\
\hline \multirow[t]{2}{*}{ 8) } & $\begin{array}{l}\text { Housing } \\
\text { Condition }\end{array}$ & $\begin{array}{c}\text { Homeless } \\
\text { Live in adequate } \\
\text { housing } \\
\text { Live in inadequate } \\
\text { housing }\end{array}$ & $\begin{array}{c}04 \\
122\end{array}$ & $\begin{array}{c}1.4 \% \\
43.8 \%\end{array}$ \\
\hline & & Total $=278$ & & \\
\hline 9) & Health Status & $\begin{array}{c}\text { Receiving } \\
\text { antiretroviral } \\
\text { treatment }\end{array}$ & 28 & $9.7 \%$ \\
\hline
\end{tabular}


Are Socio-Economic Determinants Important for Patient's Knowledge, Attitude and Practice: Evidence from Hepatitis-C Patients

\begin{tabular}{|c|l|c|c|c|}
\hline & & $\begin{array}{c}\text { Not Receiving } \\
\text { antiretroviral } \\
\text { treatment }\end{array}$ & 250 & $90.3 \%$ \\
\hline & & Total=278 & & \\
\hline 10$)$ & $\begin{array}{l}\text { Drug and other } \\
\text { Substance Use }\end{array}$ & $\begin{array}{c}\text { Yes } \\
\text { No }\end{array}$ & - & - \\
\hline & & Total= 278 & & $100 \%$ \\
\hline
\end{tabular}

The above table shows that the majority patients of HCV were male $(54.51 \%)$. Similarly, the majority patients of HCV were Urban $(80.5 \%)$, unemployed $(53.00 \%)$, low educational status $(61.4 \%)$, low income $(70.8 \%)$, live in inadequate housing $(54.6 \%)$ and not receiving antiretroviral treatment $(90.3 \%)$.

Table 2. Knowledge, attitude and practice of the patients

\begin{tabular}{|l|c|c|c|c|}
\hline Questions category & Yes & No & Total & P value \\
\hline \multirow{3}{*}{} & $\mathrm{n}$ & $\mathrm{n}$ & $\mathrm{n}$ & \\
\cline { 2 - 5 } & $\%$ & $\%$ & $\%$ & \\
\hline
\end{tabular}

\section{Knowledge Questions}

\begin{tabular}{|l|c|c|c|c|}
\hline Ever heard about HCV? & $\begin{array}{c}128 \\
(46.2 \%)\end{array}$ & $\begin{array}{c}150 \\
(53.8 \%)\end{array}$ & $\begin{array}{c}278 \\
(100 \%)\end{array}$ & 0.02 \\
\hline Are these Viral Diseases? & $\begin{array}{c}196 \\
(70.8 \%)\end{array}$ & $\begin{array}{c}82 \\
(29.2 \%)\end{array}$ & $\begin{array}{c}278 \\
(100 \%)\end{array}$ & 0.00 \\
\hline $\begin{array}{l}\text { Hepatitis can be caused } \\
\text { by viruses? }\end{array}$ & $\begin{array}{c}28 \\
(9.7 \%)\end{array}$ & $\begin{array}{c}250 \\
(90.3 \%)\end{array}$ & $\begin{array}{c}278 \\
(100 \%)\end{array}$ & 0.00 \\
\hline $\begin{array}{l}\text { Can be Transmitted by } \\
\text { Contaminated blood? }\end{array}$ & $\begin{array}{c}48 \\
(17.0 \%)\end{array}$ & $\begin{array}{c}230 \\
(83.0 \%)\end{array}$ & $\begin{array}{c}278 \\
(100 \%)\end{array}$ & 0.00 \\
\hline $\begin{array}{l}\text { Can be Transmitted by } \\
\text { unsterilized syringes and } \\
\text { instrument? }\end{array}$ & $\begin{array}{c}76 \\
(27.2 \%)\end{array}$ & $\begin{array}{c}202 \\
(72.9 \%)\end{array}$ & $\begin{array}{c}278 \\
(100 \%)\end{array}$ & 0.00 \\
\hline $\begin{array}{l}\text { Can be transmitted by } \\
\text { Sexual intercourse? }\end{array}$ & $\begin{array}{c}222 \\
(80.1 \%)\end{array}$ & $\begin{array}{c}56 \\
(19.1 \%)\end{array}$ & $\begin{array}{c}278 \\
(100 \%)\end{array}$ & 0.00 \\
\hline $\begin{array}{l}\text { Can be Transmitted by } \\
\text { barber used infected } \\
\text { blades? }\end{array}$ & $\begin{array}{c}(46.2 \%) \\
(53.8 \%)\end{array}$ & $\begin{array}{c}1278 \\
(100 \%)\end{array}$ & 0.00 \\
\hline
\end{tabular}

\section{Attitude Questions}

\begin{tabular}{|c|c|c|c|c|}
\hline $\begin{array}{l}\text { Hepatitis C Consider a } \\
\text { major health problem? }\end{array}$ & $\begin{array}{c}38 \\
13.4 \%\end{array}$ & $\begin{array}{c}240 \\
86.6 \%\end{array}$ & $\begin{array}{c}278 \\
100 \%\end{array}$ & 0.00 \\
\hline $\begin{array}{l}\text { HCV treatment is } \\
\text { unimportant? }\end{array}$ & $\begin{array}{c}194 \\
70.0 \%\end{array}$ & $\begin{array}{c}84 \\
30.0 \% \\
\end{array}$ & $\begin{array}{c}278 \\
100 \% \\
\end{array}$ & 0.00 \\
\hline $\begin{array}{l}\text { It's safe to Visit HCV } \\
\text { infected friend/relative? }\end{array}$ & $\begin{array}{c}175 \\
63.2 \%\end{array}$ & $\begin{array}{c}102 \\
36.8 \%\end{array}$ & $\begin{array}{c}278 \\
100 \%\end{array}$ & 0.00 \\
\hline $\begin{array}{l}\text { Hepatitis } C \text { virus } \\
\text { medications are not } \\
\text { needed? }\end{array}$ & $\begin{array}{c}209 \\
75.5 \%\end{array}$ & $\begin{array}{c}69 \\
24.4 \%\end{array}$ & $\begin{array}{c}278 \\
100 \%\end{array}$ & 0.00 \\
\hline $\begin{array}{l}\text { Feeling ashamed prevents } \\
\text { seeking hepatitis } C \text { virus } \\
\text { treatment? }\end{array}$ & $\begin{array}{c}162 \\
58.5 \%\end{array}$ & $\begin{array}{c}116 \\
41.5 \%\end{array}$ & $\begin{array}{c}278 \\
100 \%\end{array}$ & 0.01 \\
\hline
\end{tabular}

\begin{tabular}{|c|c|c|c|c|}
\hline Do you tested for HCV? & $\begin{array}{l}128 \\
46 \%\end{array}$ & $\begin{array}{l}150 \\
54 \%\end{array}$ & $\begin{array}{c}278 \\
100 \%\end{array}$ & 0.00 \\
\hline $\begin{array}{l}\text { Have you ever screened } \\
\text { for hepatitis C? }\end{array}$ & $\begin{array}{c}127 \\
45.6 \%\end{array}$ & $\begin{array}{c}151 \\
54.3 \%\end{array}$ & $\begin{array}{c}278 \\
100 \%\end{array}$ & 0.00 \\
\hline $\begin{array}{l}\text { Cover open wounds and } \\
\text { sores? }\end{array}$ & $\begin{array}{c}55 \\
19.8 \%\end{array}$ & $\begin{array}{c}223 \\
80.2 \%\end{array}$ & $\begin{array}{c}278 \\
100 \%\end{array}$ & 0.00 \\
\hline $\begin{array}{l}\text { Have you ever } \\
\text { participated in health } \\
\text { education Programme } \\
\text { related to hepatitis? }\end{array}$ & $\begin{array}{c}20 \\
7.1 \%\end{array}$ & $\begin{array}{c}258 \\
92.8 \%\end{array}$ & $\begin{array}{c}278 \\
100 \%\end{array}$ & 0.00 \\
\hline $\begin{array}{l}\text { Use others used tooth } \\
\text { brush / razor? }\end{array}$ & $\begin{array}{l}168 \\
60 \%\end{array}$ & $\begin{array}{c}110 \\
39.6 \%\end{array}$ & $\begin{array}{c}278 \\
100 \%\end{array}$ & 0.00 \\
\hline
\end{tabular}

Table 3. Logistic regression analysis

\begin{tabular}{|l|c|c|c|c|c|}
\hline $\begin{array}{l}\text { Socio-economic } \\
\text { Determinants }\end{array}$ & S.E & $\begin{array}{c}\text { Exp } \\
\text { (B) }\end{array}$ & Wald & Df & P value \\
\hline
\end{tabular}

(1) Impact of socioeconomic determinants on infected Hepatitis C patients

\begin{tabular}{|c|c|c|c|c|c|}
\hline $\begin{array}{l}\text { Gender } \\
\text { Male } \\
\text { Female }\end{array}$ & 1.125 & 8.216 & 3.508 & 1 & 0.00 \\
\hline $\begin{array}{l}\text { Age } \\
>50 \\
>60 \\
>70 \\
>80\end{array}$ & 1.245 & 7.922 & 4.746 & 1 & 0.00 \\
\hline $\begin{array}{l}\text { Marital Status } \\
\text { Married }\end{array}$ & 0.123 & 3.345 & 5.870 & 1 & 0.00 \\
\hline $\begin{array}{l}\text { Residence } \\
\text { Rural } \\
\text { Urban }\end{array}$ & 0.556 & & 0.337 & 1 & 0.00 \\
\hline $\begin{array}{l}\text { Employment Status } \\
\text { Employed } \\
\text { Not in Employment } \\
\text { Disability }\end{array}$ & 1.234 & 1.892 & 42.061 & 1 & 0.00 \\
\hline $\begin{array}{l}\text { Educational Status } \\
\text { Low educational status } \\
\text { Medium educational } \\
\text { status }\end{array}$ & 0.409 & 6.100 & 142.45 & 1 & 0.00 \\
\hline $\begin{array}{l}\text { Income Status } \\
\text { No income }\end{array}$ & 0.853 & 2.456 & 56.202 & 1 & 0.03 \\
\hline $\begin{array}{l}\text { Housing Condition } \\
\text { Live in adequate } \\
\text { housing } \\
\text { Live in inadequate } \\
\text { housing }\end{array}$ & 0.338 & $\begin{array}{c}0.388 \\
7\end{array}$ & 1.867 & 1 & 0.01 \\
\hline $\begin{array}{l}\text { Health Status } \\
\text { Receiving antiretroviral } \\
\text { treatment } \\
\text { Not Receiving } \\
\text { antiretroviral treatment }\end{array}$ & 0.245 & 1.885 & 23.345 & 1 & 0.02 \\
\hline $\begin{array}{l}\text { Drug and Other } \\
\text { substance user } \\
\text { No }\end{array}$ & 1.435 & 4.234 & 3.650 & 1 & 0.00 \\
\hline
\end{tabular}


2. Knowledge, Attitude and Practice of Patients towards Hepatitis $C$ virus

\begin{tabular}{|c|c|c|c|c|c|}
\hline & S.E & $\begin{array}{l}\text { Exp } \\
\text { (B) }\end{array}$ & Wald & Df & $\begin{array}{c}\mathrm{P} \\
\text { value }\end{array}$ \\
\hline \multicolumn{6}{|l|}{2 (a) Knowledge } \\
\hline $\begin{array}{l}\text { Ever heard about } \\
\text { HCV? }\end{array}$ & 0.110 & 1.250 & 4.979 & 1 & 0.02 \\
\hline $\begin{array}{l}\text { Are these Viral } \\
\text { Diseases? }\end{array}$ & 0.112 & 2.682 & 77.974 & 1 & 0.00 \\
\hline $\begin{array}{l}\text { Hepatitis can be } \\
\text { caused by viruses? }\end{array}$ & 0.120 & 0.286 & 109.859 & 1 & 0.00 \\
\hline $\begin{array}{l}\text { Can be Transmitted } \\
\text { by Contaminated } \\
\text { blood? }\end{array}$ & 0.146 & 6.500 & 163.90 & 1 & 0.00 \\
\hline $\begin{array}{lr}\text { Can be } & \text { Transmitted } \\
\text { by } & \text { unsterilized } \\
\text { syringes } & \text { and } \\
\text { instrument? }\end{array}$ & 0.132 & 4.870 & 143.45 & 1 & 0.00 \\
\hline $\begin{array}{l}\text { Can be transmitted by } \\
\text { Sexual intercourse? }\end{array}$ & 0.108 & 2.240 & 56.201 & 1 & 0.00 \\
\hline $\begin{array}{l}\text { Can be Transmitted } \\
\text { by barber used } \\
\text { infected blades? }\end{array}$ & 0.122 & 0.270 & 116.36 & 1 & 0.00 \\
\hline \multicolumn{6}{|l|}{2 (b) Attitude Questions } \\
\hline $\begin{array}{l}\text { Hepatitis C Consider } \\
\text { a major health } \\
\text { problem? }\end{array}$ & 0.163 & 8.643 & 175.10 & 1 & 0.00 \\
\hline $\begin{array}{l}\text { HCV treatment is } \\
\text { unimportant? }\end{array}$ & 0.104 & 0.540 & 35.028 & 1 & 0.00 \\
\hline $\begin{array}{l}\text { It's safe to Visit HCV } \\
\text { infected } \\
\text { friend/relative? }\end{array}$ & 0.102 & 1.647 & 23.704 & 1 & 0.00 \\
\hline $\begin{array}{l}\text { Hepatitis } C \text { virus } \\
\text { medications are not } \\
\text { needed? }\end{array}$ & 0.105 & 0.511 & 40.818 & 1 & 0.00 \\
\hline $\begin{array}{l}\text { Feeling ashamed } \\
\text { prevents seeking } \\
\text { hepatitis } C \text { virus } \\
\text { treatment? }\end{array}$ & 0.100 & 0.784 & 5.899 & 1 & 0.01 \\
\hline
\end{tabular}

\begin{tabular}{|c|c|c|c|c|c|}
\hline \multicolumn{6}{|l|}{2 (c) Practice Questions } \\
\hline $\begin{array}{l}\text { Do you tested for } \\
\text { HCV? }\end{array}$ & & & & & \\
\hline $\begin{array}{l}\text { Have you ever } \\
\text { screened for hepatitis } \\
\text { C? }\end{array}$ & 0.111 & 0.382 & 74.935 & 1 & 0.00 \\
\hline $\begin{array}{l}\text { Cover open wounds } \\
\text { and sores? }\end{array}$ & 0.169 & 0.256 & 56.103 & & 0.00 \\
\hline $\begin{array}{l}\text { Have you ever } \\
\text { participated in health } \\
\text { education Programme } \\
\text { related to hepatitis? }\end{array}$ & 0.109 & 2.374 & 61.764 & 1 & 0.00 \\
\hline $\begin{array}{l}\text { Use others used tooth } \\
\text { brush / razor? }\end{array}$ & 0.110 & 0.406 & 67.510 & 1 & 0.00 \\
\hline
\end{tabular}

3. Knowledge, Attitude and Practice

\begin{tabular}{|l|l|l|l|l|}
\hline Variable & S.E & $\operatorname{Exp}(\mathrm{B})$ & Df & P value \\
\hline Knowledge & 0.132 & 4.870 & 1 & 0.00 \\
\hline Attitude & 0.100 & 0.784 & 1 & 0.00 \\
\hline Practice & 0.109 & 2.374 & 1 & 0.01 \\
\hline
\end{tabular}

Dependent Variable: Knowledge, Attitude and Practice, Independent Variable: Gender, Age, Marital Status, Educational Status, Employment Status, Income Status, Housing Condition, Health Status and Drug and Substance User.

By applying Logistic regression, there was a significant difference that have poor knowledge, negative attitude and poor practices towards HCV due to low socioeconomic determinants which was evident from the obtained value that is $p<0.05$. The results reported that the socioeconomic determinants have a significant effect on patient's knowledge, attitude and practice towards $\mathrm{HCV}$.

\section{Discussion}

The total sample of the current study was 278. Male participants were $152(54.51 \%)$ while female participants were 126(45.49\%). According to age, which shows that mostly patients between $>50$ years of age which were 66(23.8\%), >60 years were 109 $(39.4 \%),>70$ years were $50(17.8 \%),>80$ years were $53(19.0 \%)$. According to marital status, $278(100 \%)$ participants including male and female were married. According to Residency, patients were rural 54(19.5\%), while $223(80.5 \%)$ patients were urban. According to employment status, $135(49.65 \%)$ patients were employed, while 138(49.6\%) patients were unemployed. $5(1.7 \%)$ patients were disabled. According to educational status, 170 (61.4\%) patients had low educational status, while $108(38.8 \%)$ patients had medium educational status. According to income status, $196(70.8 \%)$ patients had low income, while $82(29.2 \%)$ patients had no income. According to housing condition, $122(43.8 \%)$ patients were living in adequate housing, 152(54.6\%) were living in inadequate housing, but $4(1.4 \%)$ were homeless. According to health status, $28(9.7 \%)$ patients were receiving antiretroviral treatment, while 250(90.3\%) patients were not receiving antiretroviral treatment. $278(100 \%)$ patients were not drug and other substance user.

The results of the current study reported that the patients have poor knowledge and negative attitude towards $\mathrm{HCV}$ hepatitis $\mathrm{C}$ due to socioeconomic determinants such as no proper knowledge, helpless peoples, low income, low status, educational status and diminishing danger factors. A study reported that more positive attitudes of health care workers toward the patients with HCV was affected directly by levels 
of knowledge, clinical experience, and older age of respondents (15). Another study revealed that rural population had negative attitude towards the patients of hepatitis B and C. Further results also indicated that people having low income and less education also had negative attitude towards $\mathrm{HCV}$, which may be due to lack of knowledge about the disease (17). The finding of the current study reported that 196 (70.8\%) patients had low income and $82(29.2 \%)$ patients had no income. A current study evaluated the socioeconomic features of hepatitis $C$ patients in Iran. The results of this study indicate a low level of knowledge about $\mathrm{HCV}$, especially in nature of disease, prevention and treatment strategy. More educated worker reported better knowledge toward viral hepatitis (10).

A study concluded that lack of imperative knowledge of hepatitis in patients was the main reason for negative attitude and poor practices. (19). According to WHO, $2.8 \%$ of the world's population is infected with HCV (20). It is also determined that the low knowledge about the HCV was found to be seen as related with negative attitude of the peoples $(21,22)$.

In the current study the regression analysis reported that socioeconomic determinants have effects on patient's knowledge, attitude and practices towards $\mathrm{HCV}$. Another study revealed that the $p$-values were statistically significant $(<0.005)$ in both categories of knowledge and attitude that has effect on patient's socioeconomic determinants (5). The poor knowledge of HCV infection among patients was $80 \%$ as well as the prevalence of $\mathrm{HCV}$ infection was $60 \%$ that was transmitted by contaminated blood, sexual contact and with the use of infected blades. This could be because of lower Knowledge of HCV infection in the hospitals and negative attitude towards hepatitis $C$ virus reported in Ethiopia (23). Recent research shows that HCV knowledge and awareness is very low among general population in Pakistan, particularly among women and less educated people (24). A negative attitude of patients towards hepatitis $C$ virus was affected directly by levels of knowledge, educational status and older age. Increasing the knowledge about hepatitis $C$ and highlighting the efficiency of standard infection control precautions for preventing transmission of hepatitis C may have an important role about patients feeling confident during care about hepatitis $C$ and preventing fear of contracting hepatitis $\mathrm{C}$ and increasing willingness to treatment (25).

\section{Conclusion}

Poor knowledge, negative attitude and bad practices towards $\mathrm{HCV}$ were the main reasons behind poor socioeconomic determinants. The results of this study indicate a low level of knowledge about the HCV infection, especially in the nature of disease and its prevention. Poor knowledge, helpless peoples, low income, low status, inadequate housing conditions and educational status effects on patient's health. HCV related knowledge and awareness among people of Pakistan is inadequate. It is necessary to enhance the knowledge and awareness about HCV that ultimately can lead to better attitude towards the disease and its prevention. Continuous training program toward viral infection is a need of time.

\section{References}

1. World Health Organization, (2017). Global hepatitis report. Available at: https://www.who.int/hepatitis/publications/globalhepatitis-report2017/en/external icon

2. Lawitz E, Mangia A, Wyles D, Rodriguez-Torres M, Hassanein T, Gordon SC, Schultz M, Davis MN, Kayali Z, Reddy KR, Jacobson IM. Sofosbuvir for previously untreated chronic hepatitis C infection. New England Journal of Medicine. 2013 May 16;368(20):1878-87.

3. Atlam SA, Elsabagh HM, Shehab NS. Knowledge, attitude and practice of Tanta University medical students towards hepatitis B and C. International Journal of Research in Medical Sciences. 2016 Mar;4(3):749-56.

4. KVITKO DT, BASTOS GA, PINTO ME. Prevalence of risk factors for hepatitis $\mathrm{C}$ and associated factors: a population-based study in southern Brazil. Arquivos de gastroenterologia. 2013 Jun;50(2):117-22.

5. Mengal MH, Tanver F, Azam M, Mengal MA, Mengal MA, Taj MK. Cross sectional assessment of knowledge, attitude and practice towards Hepatitis C among adolescents in Quetta, Pakistan. Dentistry. 2014 Jan 1;4(10):1.

6. Corneil TA, Kuyper LM, Shoveller J, Hogg RS, Li K, Spittal PM, Schechter MT, Wood E. Unstable housing, associated risk behaviour, and increased risk for HIV infection among injection drug users. Health \& place. 2006 Mar 1;12(1):79-85.

7. Rueda S, Raboud J, Mustard C, Bayoumi A, Lavis JN, Rourke SB. Employment status is associated with both physical and mental health quality of life in people living with HIV. AIDS care. 2011 Apr 1;23(4):435-43.

8. Rourke SB, Sobota M, Tucker R, Bekele T, Gibson K, Greene S, Price C, Koornstra JJ, Monette L, Byers S, Watson J. Social determinants of health associated with hepatitis C co-infection among people living with HIV: 
results from the Positive Spaces, Healthy Places study. Open Medicine. 2011;5(3):e120.

9. Ha S, Totten S, Pogany L, Wu J, Gale-Rowe M. Infectious Disease as Chronic Disease: Hepatitis $C$ in Canada and the importance of risk-based screening. Canada Communicable Disease Report. 2016 Mar 3;42(3):57.

10. Joukar F, Mansour-Ghanaei F, Naghipour MR, Hasandokht T. Nurses' knowledge toward hepatitis B and hepatitis $C$ in Guilan, Iran. The open nursing journal. 2017;11:34.

11. ul Haq N, Hassali MA, Shafie AA, Saleem F, Farooqui $\mathrm{M}$, Aljadhey H. A cross

sectional assessment of knowledge, attitude and practice towards Hepatitis B among healthy population of Quetta, Pakistan. BMC Public Health. 2012; 12(1): 692

12. Shalmani HM, Ranjbar $M$ \& Alizadeh AHM. Recommendations for prevention and control of hepatitis $\mathrm{C}$ virus (HCV) infection and HCV-related chronic disease. J Liver. 2013; 3(147): 2167-0889.

13. Chireh B. Knowledge, Attitude and Practices (KAP) Concerning Hepatitis B Among Adolescents in the Upper West Region of Ghana. The Rural-urban Gradient (Doctoral dissertation, Umeå International School of Public Health).

14. Qutoshi SB. Malik, R., \& Naveed, A. (2015). Financing Education in Pakistan: The Impact of Public Expenditure and Aid on Educational Outcomes. áRECOUP WP, no. 4 Dhaulagiri Journal of Sociology and Anthropology. 2017 Dec 31;11:192-8.

15. Korkmaz P, Uyar C, Ozmen A, Toka O. Knowledge and attitude of health care workers toward patients with hepatitis C infection. The Southeast Asian journal of tropical medicine and public health. 2016 Sep 1;47(5):935-44.

16. Omland LH, Osler $M$, Jepsen $P$, Krarup $H$, Weis $N$, Christensen PB, Roed C, Sørensen HT, Obel N. Socioeconomic status in HCV infected patients-risk and prognosis. Clinical epidemiology. 2013;5:163.
17. Yaseen MR, Aziz S, Aftab S. Socio-Economic Factors Affecting Hepatitis $\mathrm{C}$ and Lack of Awareness: A Case Study of Pakistan. Iranian journal of public health. 2014:1456-7.

18. Edmunds BL, Miller ER, Tsourtos G. The distribution and socioeconomic burden of Hepatitis $C$ virus in South Australia: a cross-sectional study 2010-2016. BMC public health. 2019 Dec 1;19(1):527.

19. Mustafa RE, Mushtaq S, Akhtar N, Yameen MA. Assessment of knowledge, attitude and practice towards hepatitis among patients visiting the hepatitis clinic in tertiary care hospital, Rawalpindi, Pakistan. JPMA. The Journal of the Pakistan Medical Association. 2019 Aug;69(8):1136-41.

20. https://www.who.int/news-room/factsheets/detail/hepatitis-c

21. Joukar F, Mansour-Ghanaei F, Soati F, Meskinkhoda P. Knowledge levels and attitudes of health care professionals toward patients with hepatitis $\mathrm{C}$ infection. World Journal of Gastroenterology: WJG. 2012 May 14;18(18):2238.

22. Mansour-Ghanaei R, Joukar F, Souti F, Atrkar-Roushan $Z$. Knowledge and attitude of medical science students toward hepatitis B and C infections. International journal of clinical and experimental medicine. 2013;6(3):197.

23. Lavanchy D. Hepatitis B virus epidemiology, disease burden, treatment, and current and emerging prevention and control measures. Journal of viral hepatitis. 2004 Mar;11(2):97-107.

24. Asif SA, Iqbal R, Hussain H, Khan MH. Awareness of viral hepatitis in ten villages of district Nowshera. Gomal Journal of Medical Sciences. 2009;7(1):1013.

25. Islam N, Flores $\mathrm{YN}$, Ramirez P, Bastani R, Salmerón J. Hepatitis and liver disease knowledge and preventive practices among health workers in Mexico: a crosssectional study. International journal of public health. 2014 Apr 1;59(2):381-94. 